\title{
The Landscape Attractiveness of Abandoned Quarries
}

\author{
Elżbieta Baczyńska $^{1}$ - Marek W. Lorenc ${ }^{1}$ - Urszula Kaźmierczak ${ }^{2}$
}

Received: 17 May 2016 / Accepted: 3 May 2017 /Published online: 17 May 2017

(C) The Author(s) 2017. This article is an open access publication

\begin{abstract}
This study is a trial for presenting high attractiveness of shape form in abandoned quarry areas, as well as for indicating social interest in the areas in terms of their attractiveness. For this reason, a procedure of evaluation of the landscape attractiveness of abandoned quarries is suggested, which was created by assigning additional partial criteria, and their comparison with the criteria of already existing methods. Methods used for the research are as follows: the semantic differential technique (also called Osgood's method), the entropy method, and the method of point bonitation. In order to verify the procedure suggested, 10 objects (quarries) located in the area of the Ślęża Landscape Park with its buffer zone were studied. Then, comparative studies were conducted, this time with quarries from Great Britain and Austria, also subject to some forms of environmental protection. The results of the research suggest that the main indicator of a quarries' attractiveness is their uniqueness, aesthetic appeal, interest, and the curiosity they raise, which allows the formation of four classification groups for attractiveness: very attractive, attractive, slightly attractive, and unattractive quarries. The research
\end{abstract}

Elżbieta Baczyńska

baczynska.e@gmail.com

Marek W. Lorenc

marek.lorenc@up.wroc.pl

Urszula Kaźmierczak

urszula.kazmierczak@pwr.edu.pl

1 Wroclaw University of Environmental and Life Sciences, Faculty of Environmental Engineering and Geodesy, ul. Grunwaldzka 55, 50-357 Wrocław, Poland

2 Wroclaw University of Technology, Faculty of Geoengineering, Mining and Geology, Wybrzeże Wyspiańskiego 27, 50-365 Wrocław, Poland conducted also indicates that highly attractive quarries may gain a larger number of tourists and the development of hiking, cycling, horse riding, and, in some cases, also qualified tourism (rock climbing or diving) through creating additional side attractions. Additionally, due to their uniqueness and form differentiation, abandoned quarries may be used for common social education, being a didactic place in programmes of touristic trips, science lessons, and ecological education.

Keywords Quarries $\cdot$ Landscape $\cdot$ Rock mining $\cdot$ Post-mining areas $\cdot$ Geotourism

\section{Introduction}

Areas of abandoned quarries are an important element of the environment in terms of both their regional and national meaning. Excavated holes left after exploitation of solid rock minerals are characterised by many features, due to which we may talk about their own "landscape". Quarries make interesting morphological forms and, thus, they become specific landmarks. They can have good localisation, often close to large cities or communication nodes. Furthermore, old mining excavations, due to rapid natural succession processes, become precious natural habitats of many flora and fauna species, but they also can be potential places for municipal and industrial waste disposal (Kaźmierczak et al. 2014; Kasztelewicz and Ptak 2011; Xiao et al. 2011; Raska et al. 2011; Kaźmierczak and Malewski 2000; Paulo 2008; Malewski 1999; Coppin and Bradshaw 1982). What is more, it is worth noting that such places possess local cultural values and may be an important element for tourism attraction. Their use by tourist routes may contribute to boosting the tourist industry and raising regional touristic attractiveness through 
making additional attractions, created on the basis of transformations that came into existence due to excavation. Consequently, newly created, after exploitation of rock minerals, landscape forms may occur and become an attractive element of the environment that attracts tourists (Migon and Pijet-Migoń 2015; Lorenc and Baczyńska 2013; Lorenc and Mazurek 2010; Shoval and Raveh 2003; Swarbroke 2002; Coppin and Box 1998; Goodall 1990). However, such landscape forms and the changing trends of society's likes and dislikes are often arguments concerning for reclamation and management of the areas. The issue is the potential for evaluating abandoned quarry landscape attractiveness and their utilisation for tourism with local historical and natural values being taken into account.

In order to select the best management and, consequently, the way of reclamation, it is essential to consider many aspects (Kaźmierczak et al. 2014). One of these is public preferences related to the evaluation of attractiveness of post-exploitation areas, their social acceptance, but also the terrain, preservation of the excavation hole, and pace of natural succession. As quite specific landscape forms, quarries may be perceived by individuals as more or less attractive. Accordingly, facing the problem of assessing attractiveness of post-exploitation areas of solid rock minerals becomes a vital issue. Currently existing methods of landscape evaluation are difficult to directly implement in the evaluation of abandoned quarries without introducing some additional partial criteria. Therefore, assigning such criteria and their integration with the criteria of existing methods was used to develop a procedure for assessing quarry attractiveness, which is the subject of this paper.

\section{Research Methods}

In order to determine some additional partial criteria and integrate them with the criteria of pre-existing methods, which are the basis for developing the procedure of abandoned quarry landscape attractiveness, three research methods were used, after modifications of a procedure for attractiveness evaluation. They are the following:

- The survey method with a semantic differential

- An evaluation of the number of signals coming from a landscape through the assessment of landscape entropy

- The method of point "bonitation"

\section{The Survey Method with a Semantic Differential}

The sample group for the survey comprised tourists and inhabitants of neighbouring towns who visited the selected quarries (c.1000 people). The choice of the group was completely accidental and the survey was anonymous. The survey aimed to determine connotations of the word "quarry", the distance travelled by the surveyed to use the area of an abandoned quarry, and the frequency of use and diagnose the values through the evaluation of attractiveness based on the selection of negative or positive features of the researched quarries. In addition, using a semantic differential for the analysis and then the assessment of abandoned quarry landscape attractiveness allows the presentation of the preferences of the respondents in relation to the analysed areas, and it is one of the factors of the method used for the attractiveness evaluation. An important aspect of the method is that it allows the selection of the human factor in the attractiveness evaluation and human feelings related to the area.

A semantic differential is a kind of measuring scale used for the assessment of connotations. In language semantics, it means appointing a meaning to a word, using words rooted in social awareness and emerging in the language. A characteristic feature of the measuring scale is that its poles (the beginning and end of the scale) are marked with two antonyms: bad-good, cheap-expensive, useless-useful, etc. (Babbie 2010; Kruczek 2011; Osgood et al. 1957). Between those extreme characteristics, there are a few intermediate categories marked implicitly with natural numbers. Using contrary definitions creates a point scale of marks. The form of analysis is a drawing of the graphic profile. It is made by connecting with a line the numbers achieved by the object researched on each evaluation scale (Kruczek 2011; Steinberg and Jakobovits 1971). For that reason, the following statistics are calculated: the average value for each pair of contrasting features and the synthetic indicator of the facility assessment in the average form calculated together for all of the pairs of evaluated features. The advantages of the scale are, in particular, the ease of communicating the conclusions and the good measurement of attitude intensity towards the object researched.

Additionally, the differential allows a quantitative assessment in the meaning of defined concepts for various groups, e.g. research on social stereotypes (Kothari 2004; Osgood et al. 1957). It also allows the definition of the emotional component of attitudes towards various objects, e.g. of tourists towards attractions. At the same time, it enables specifying changes of emotional meaning for various concepts in time, e.g. enables tracking changes. The method may be implemented in the evaluation of various intended activities, e.g. while evaluating the efficiency of implementation of new forms of land management. It may be used for needs analysis, so it is a useful method for planning various activities. 


\section{The Research of Landscape Entropy}

The research on entropy was conducted directly on the basis of field studies, and the results made possible by grouping the units depending on the number of stimuli in the area given. Entropy is a notion connected with landscape perception, as it relates to the amount of information carried by the landscape. The process of perception is receiving signals with the senses; next, the phase of associations and expressing the aesthetic assessment take place. Nevertheless, the patterns referred to in landscape evaluation are not constant. They are subjected to modification along with civilisational and cultural changes (Polska 2011). In entropy, a landscape is to be perceived as a multisensory unit, as in each and every case, it is perceived by a human with many senses, which affect them to a greater or lesser degree. In other words, the multisensory landscape is an existing structural and territorial reality perceived with senses and delivering a set of signals through channels, thus becoming stimuli for receptors (Bartkowski 1992; Bernat 2004). The existence of signals is conditioned by a landscape's structure and functioning (Kowalczyk 2004). Potential sources of signals from a quarry landscape are received through the senses of sight, hearing, smell, and touch. Most information received by a human is through sight $(80-90 \%)$, while the other senses receive 10-20\% of information (Młodowski 1998). Therefore, the received signals may be divided into two groups: those perceived with sight (I) and those perceived with the other senses (II).

For the purpose of developing the procedure of the landscape attractiveness evaluation, the source of communicates was subjected to consideration, the source which may transmit 19 different signals (both positive and negative), marked respectively $1,2 \ldots 19$. Therefore, the assumption was accepted that they decompose into two groups: I (perceived with the sense of sight): 1, 2, 3, 4, 5, 6, 7, 8, 9, and II (perceived with the other senses): 10, $11,12,13,14,15,16,17,18,19$; this is while taking into account that the occurrence of the group I signals is equally probable to the occurrence of the group II signals. The communicates in group I $(1,2 \ldots 9)$ will be equally probable, while those from group II comprise equally probable subgroups: IIA $(10,11,12,13)$, IIB $(14,15,16,17)$, and IIC $(18,19)$. The probability of the signals' occurrence in all three subgroups is assumed to be equal (Turski 1989). In this method, a signal sent by a landscape element and received by one of the senses is called the occurrence. Then, if a signal is sent and received by the sense of sight, one of the nine occurrences will happen, whereas when a signal from the other group takes place, one of the other 10 occurrences will happen (Fig. 1).
This method also assumes that all of the accepted signals do not exist in the landscape, but only some of them, which makes the method useful for landscape evaluation. The probability of presence of the signals is conditioned by the component characteristics of the landscape, which are accepted signal sources. Therefore, if a landscape may transmit an $n$ number of signals - in this case 19-with the probability of occurrence $p_{i}$, and $i=1,2 \ldots n$, then the weighted average amount of information coming from the landscape, which is the information entropy of the information source, may be counted using the formula (Steinberg and Jakobovits 1971):

$H=\sum_{i=1}^{n} p_{i} \log _{2}\left(\frac{1}{p_{i}}\right)$

The result will be the achievement of three kinds of landscapes:

- Strongly stimulating landscape

- Moderately stimulating landscape

- Slightly stimulating landscape

In order to adjust the method to the procedure of abandoned quarries' landscape attractiveness evaluation, the individual landscapes were assigned the right number of points (Table 1).

\section{The Method of Point "Bonitation"}

The used method of point "bonitation" was to isolate from the quarries' landscape area, the elements of a natural and anthropogenic environment that are carriers of their possible values, and to specify their attractiveness and aesthetic appeal. The "bonitation" method assumes the "bonitation" scale, which presents the relationship between the accepted environmental or landscape variable and the number of points (Bartkowski 1986; Rutkowski 1978; Śleszyński 1999; Dubel 2000; Bezkowska 2005; Kożuchowski 2005). This method was first used in the interwar period by Leszczycki $(1937,1938)$ to determine tourist attractiveness of the geographical environment of Podhale and the level of development of this region. This method is subjective with regard to the selection of a value scale at the researcher's discretion and consists in giving points according to the selected value scale to the particular features. This method also allows one to use additional points describing qualitative features of the resources occurring within the area. The points are usually given within designated areas. Most of the research studies using point "bonitation" consider a particular ground sector as a basic area. The whole analysed area is divided into squares of the same dimensions. The next stage sums up the points referring to the particular features.

The method was adapted for the purpose of the research by assuming the quarries' interiors for primary fields. Moreover, 
Fig. 1 Division of notices (after Kowalczyk 2004)

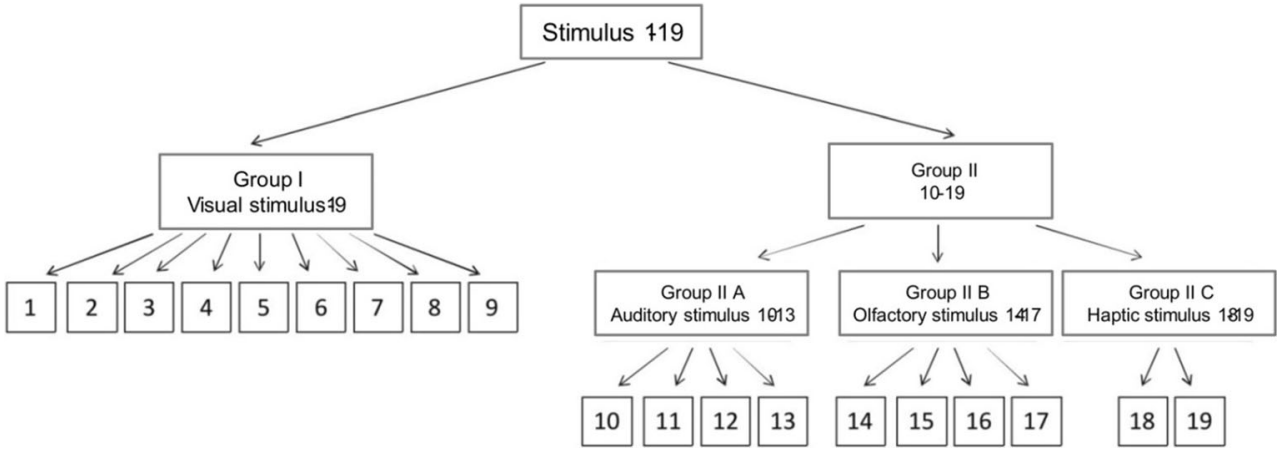

additional assumptions were made: restricting the understanding of landscape attractiveness, excluding touristic infrastructure and the burden on the environment resulting from touristic usage. Furthermore, the criteria accepted in the method include:

- Vertical differentiation of the area:

- Over $25 \mathrm{~m}-5$ points

- $21-25 \mathrm{~m}-4$ points

- $16-20 \mathrm{~m}-3$ points

- $10-15 \mathrm{~m}-2$ points

- 5-10 m-1 point

- Below $5 \mathrm{~m}-0$ point

- The percentage of natural succession:

- Below 10\%-5 points

- $10-29 \%-4$ points

- 30-49\%-3 points

- 50-69\%-2 points

- $70-89 \%-1$ point

- $90-100 \%-0$ point

- Boundary contrasts for particular types of land cover (Table 2)

- The state of quarry preservation:

- Good-2 points

- Average-1 point

- Bad-0 point

- The number of adjacent area types:

- 3 and more-3 points

- $2-2$ points

- $1-1$ point

- The lack of differences between the quarry and adjacent area -0 point

Table 1 The entropy rate

\begin{tabular}{ll}
\hline Entropy divisions & Points \\
\hline Strongly stimulating landscapes over 6.00 & 2 \\
Moderately stimulating landscapes from 6.00 to 3.00 & 1 \\
Slightly stimulating landscapes below 3.00 & 0 \\
\hline
\end{tabular}

Furthermore, if one quarry bordered many types of adjacent areas, the points were awarded according to the formula:

$\left.W_{k}=\frac{\left(L_{1} x K_{1}+L_{2} \times K_{2}+L_{n} \times K_{n}\right)}{100}\right)$

where:

$W_{k} \quad$ indicator of boundary contrasts

$L_{n} \quad$ percentage of the area bordering $n$-type area

- The presence of surface waters:

- Entire quarry interior - 4 points

- Close vicinity of a huge reservoir - 3 points

- Huge reservoir making 40-60\% of quarry area-2 points

- Small reservoir making $10-30 \%$ of quarry area -1 point

- Lack of surface waters - 0 point

- Road, route accessibility:

- Good-2 points

- Average-1 point

- Very aggravated -0 point

Additional points were also awarded for protection forms in the area given. The existing protection forms in the area may significantly influence the will of tourists and hence the frequency of visits who treat them as "another attraction" worth visiting. Thus, every quarry subjected to a form of protection was given an additional point.

In the research, attention was also paid to the negative anthropogenic factor, which may significantly influence the reception and evaluation of a quarry given. Therefore, every researched site where the presence of disfiguring architectural elements was noticed - like the remains of fencing or household rubbish - received -1 point. The same was in the case of objects located near busy streets or active processing plants.

Finally, the procedure for evaluation of abandoned quarry landscape attractiveness consists of the summary assessment of individual criteria, according to the formula:

$\left.A K K=\left(W_{p}+W_{s n}+W_{s z}+W_{k}+W_{g}+W_{w}+W_{d}+W_{a}+W_{e}+W_{o}\right)-W_{n}\right)$ 
Table 2 Particular types of land cover

\begin{tabular}{lllll}
\hline \multirow{2}{*}{$\begin{array}{l}\text { Dominating type of adjacent land } \\
\text { cover }\end{array}$} & \multicolumn{2}{l}{ Dominating type of quarry land cover } \\
\cline { 2 - 5 } & Trees & $\begin{array}{l}\text { Shrub-like } \\
\text { vegetation }\end{array}$ & Grasslands & $\begin{array}{l}\text { Slight traces of natural } \\
\text { succession }\end{array}$ \\
\hline Trees & 0 & 1 & 2 & 3 \\
Shrub-like vegetation & 1 & 0 & 1 & 3 \\
Grasslands & 2 & 1 & 0 & 3 \\
Other contrasting land cover & 3 & 3 & 3 & 3 \\
\hline
\end{tabular}

where:

$\begin{array}{ll}A K K & \text { quarry landscape attractiveness } \\ W_{p} & \text { vertical differentiation indicator } \\ W_{s n} & \text { natural succession influence indicator } \\ W_{s z} & \text { quarry preservation state indicator } \\ W_{k} & \text { boundary contrast indicator } \\ W_{g} & \text { indicator of the number of adjacent area types } \\ W_{w} & \text { surface water presence indicator } \\ W_{d} & \text { road, route accessibility indicator } \\ W_{a} & \text { the respondents' evaluation indicator } \\ W_{e} & \text { entropy evaluation indicator } \\ W_{o} & \text { indicator of areas subjected to legal protection } \\ W_{n} & \text { indicator of human unfavourable activity influence }\end{array}$

\section{Research Area}

For verification of the proposed procedure, there were 10 selected research units located in the area of the Ślęża Landscape Park and its buffer zone. The area is a touristic location visited by inhabitants of Wrocław and neighbouring towns. In order to analyse the issue more deeply, comparative studies were also conducted abroad and then compared with the basic units in the Ślęża Region. The selected comparative units are located in Great Britain in the southern county of Dorset (Lorenc and Baczyńska 2013) (three units), and also in the area of the town of Adnet in Austria (seven units). The areas were selected due to their long and abundant history of mineral extraction, just like in the Ślęża Region. Moreover, they are also protected by various forms of landscape protection. Furthermore, the quarries in Great Britain and Austria are local tourist attractions.

\section{Ślęża Region}

Ten units from the Ślęża Region, located in the southwest of Poland, were subjected to specific research. For ordering the individual units, they were assigned consecutive numbers (Fig. 2).
Eight of the selected quarries are located in the Ślęża Landscape Park, and two are within the borders of its buffer zone. The areas were places of excavation of granite, gneiss, gabbro, or serpentinite. The areas are in different states of conservation, which is described below:

1. Former gneiss quarry located on the slope of Mount Kunowska, east of the town of Sobótka. The quarry area is about $4500 \mathrm{~m}^{2}$. Forceful natural succession almost completely covered the tracks of the quarry. In the area, there is a small, natural pond. It is located in the buffer zone of the Ślęża Landscape Park, and one can get there along a countryside path (Fig. 3).

2. Prehistoric quarry "Pod Wieżycą" is located between Mount Wieżyca and Mount Gozdnica, about $120 \mathrm{~m}$ from Tourist House "Pod Wieżycą", which includes a few tourist routes. It covers the area of about $5500 \mathrm{~m}^{2}$ and is the oldest prehistoric quarry of two-mica granite. The beginnings of the mineral extraction date 3500 years back. It was extracted especially intensively in the Bronze and Iron Ages by the tribe of Ślężanie, who lived there. Currently, fast and forceful natural succession covers the tracks of the quarry's existence. It is located in the Ślęża Landscape Park, and at the bottom of the quarry, there is a little stream.

3. Mediaeval granite quarry covering the area of about $1000 \mathrm{~m}^{2}$. Progressing natural succession almost completely covered the evidence of extracting the mineral, and now only few quern-stones left around mark some intensive labour in the past. Not far from that site, there is a dirt forest road. It is located in the Ślęża Landscape Park (Fig. 4).

4. Granite quarry in Chwałków_called Emerald Lake. Remote and about $3 \mathrm{~km}$ west from Sobótka centre. It was naturally filled with water and now covers about $10,000 \mathrm{~m}^{2}$. It is part of the Ślęża landscape and an attraction for a number of those who visit this place to swim, dive, and climb rocks. The quarry has good access from the local road.

5. Granite quarry in Chwałków. It is remote and about $4 \mathrm{~km}$ west from Sobótka centre. Its surface is about $5000 \mathrm{~m}^{2}$ altogether. This was also naturally filled with water. 
Fig. 2 Location of selected units in the Ślęża Region

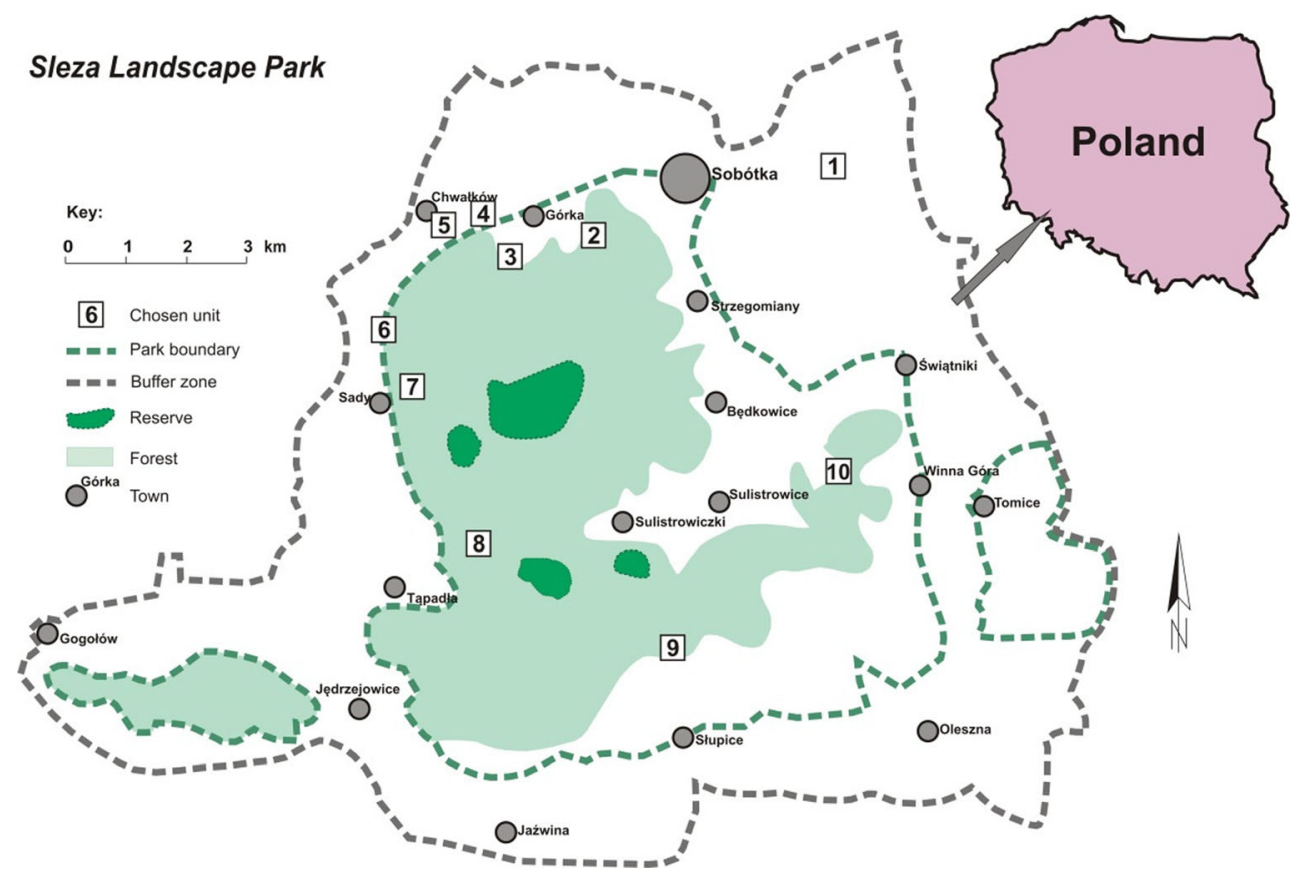

Similar to the previous one (no. 4), this quarry has very steep walls, which still remain well preserved. Very good access along the local road (Fig. 5).

6. Gabbro quarry with quartz veins located on the slope of the hill of Sadno, which is $230 \mathrm{~m}$ high. It is called "Biake Krowy". It is covered with very dense vegetation and remains hardly visible. Its area is about $3000 \mathrm{~m}^{2}$. Numerous trees and shrubs obstruct access to the quarry. It is located in the Ślęża Landscape Park (Fig. 6).

7. Granite quarry located on the slope of Mount Kwarcowa-524 m above sea level in the Ślęża Landscape Park, covering an area of about $1200 \mathrm{~m}^{2}$. In its immediate vicinity is a forest road. The average state of preservation (Fig. 7).

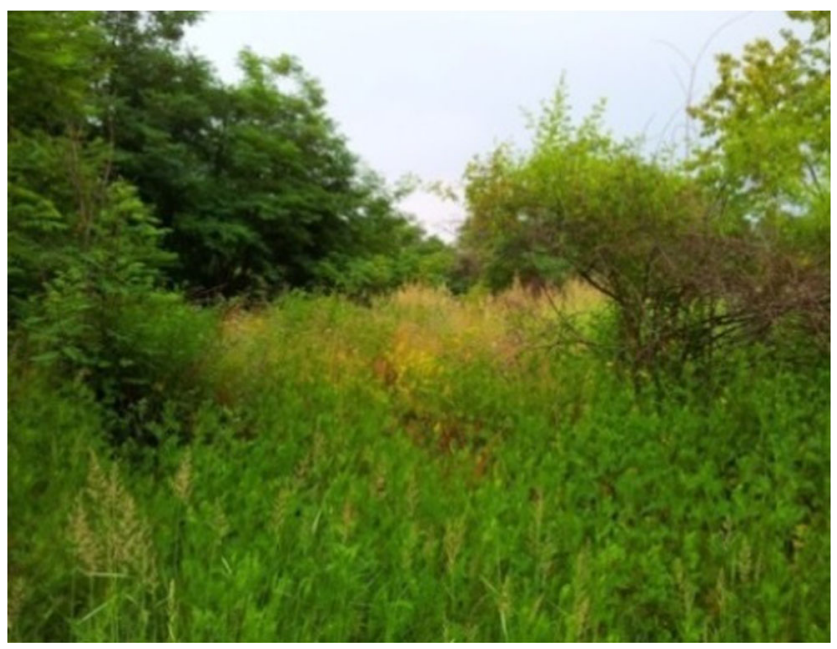

Fig. 3 Quarry no. 1
8. Former serpentinite quarry located near a local road. Forcefully progressing natural succession makes the quarry (covering about $1200 \mathrm{~m}^{2}$ ) hardly visible. The quarry is located in the Ślęża Landscape Park (Fig. 8).

9. Former serpentinite quarry located on the slope of Mount Słupicka (335 $\mathrm{m}$ above sea level), covering about $2500 \mathrm{~m}^{2}$. It is located in the Ślęża Landscape Park and is accessible by a forest road. It is protected as an ecological area. A good state of preservation.

10. Former serpentinite quarry located in the east of the village of Przemiłów in the Ślęża Landscape Park. It covers an area of about $3700 \mathrm{~m}^{2}$ and is accessible by a local road. There is a small, natural pond. It is additionally protected as an ecological area.

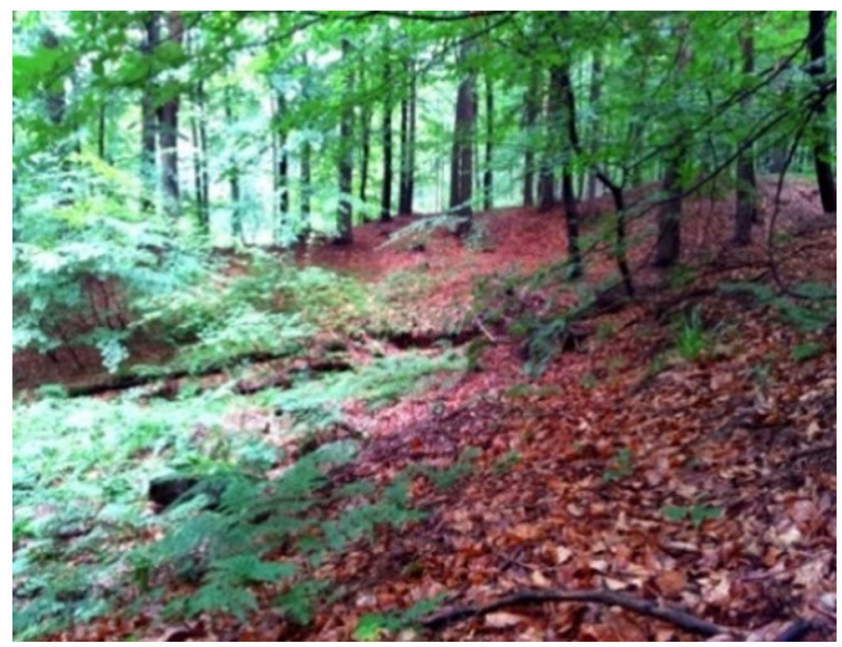

Fig. 4 Quarry no. 3 


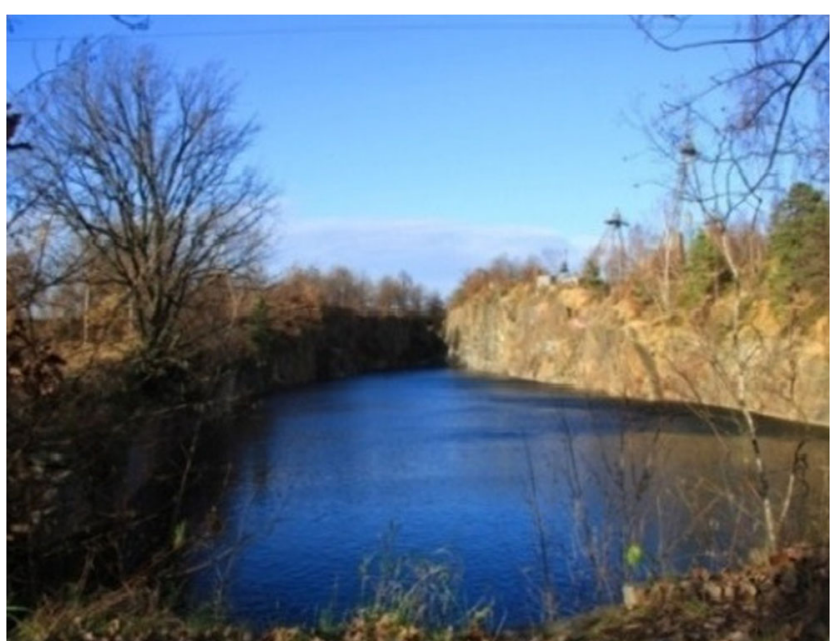

Fig. 5 Quarry no. 5

\section{Comparative Units}

Some excavation sites from Great Britain and Austria were selected as comparative units for checking the procedure of the landscape attractiveness evaluation of the abandoned quarries. The quarries from Great Britain selected for the study are located on the "Jurassic Coast" in Dorset between Swanage and Worth Matravers, and on Portland Island (Fig. 9). The Austrian units are located in the area of Adnet (Fig. 10).

As for the quarries of the Ślęża Region, they were also assigned consecutive numbers (11-13 for British units and 14-20 for Austrian units):

1. Winspit limestone quarry - located on the Jurassic Coast between St. Aldhelm's Head and Seacombe, in Old Portland Stone Cliff Quarries. It covers an area of about

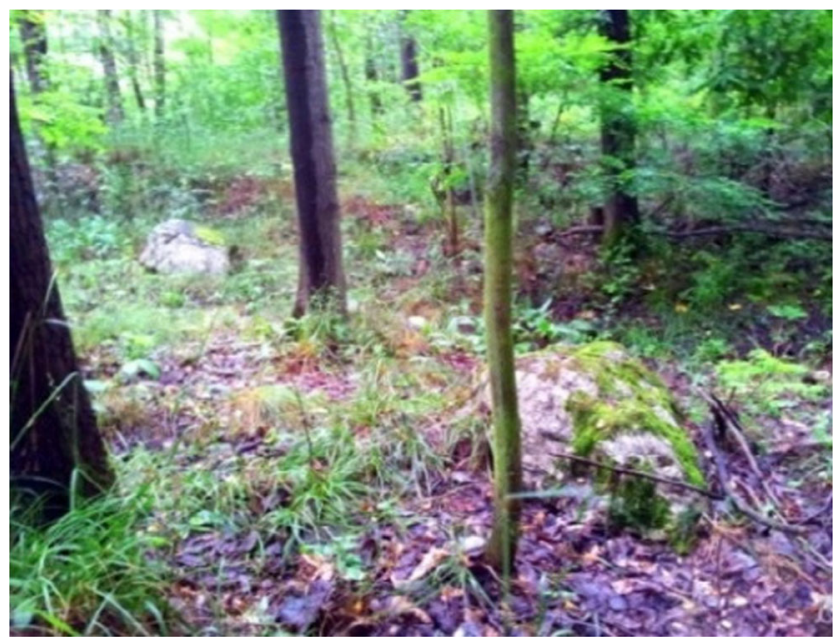

Fig. 6 Quarry no. 6

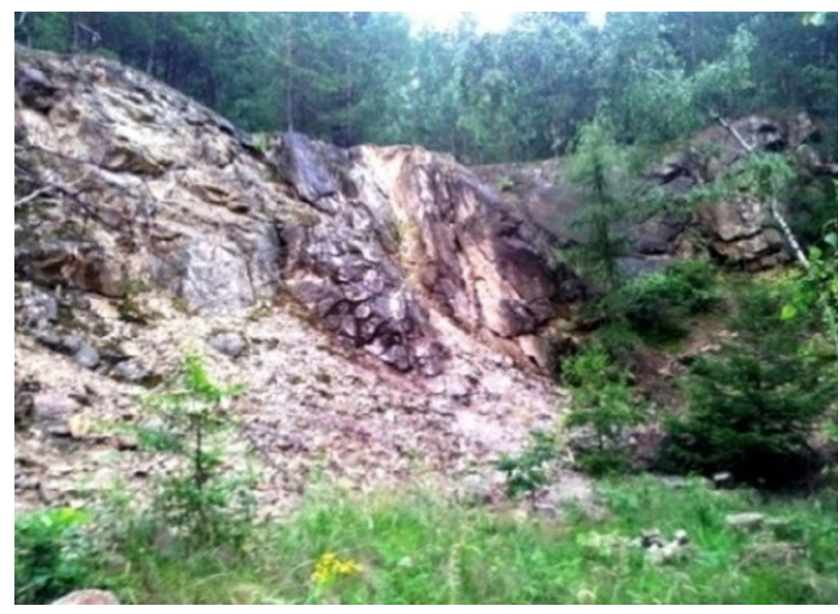

Fig. 7 Quarry no. 7

$10,000 \mathrm{~m}^{2}$ and is accessible by a local road. It is legally protected (Fig. 11).

2. Limestone quarry located on Portland Island. It has an area of about $20,000 \mathrm{~m}^{2}$ and from the east is adjacent to the English Channel. Because of its close vicinity to the ocean, it is a major tourist attraction. Additionally, some of it is characterised by almost vertical walls, which are eagerly used for climbing. It is partly legally protected (Fig. 12).

3. Limestone quarry also located on Portland Island and covering about $20,000 \mathrm{~m}^{2}$. Its characteristic features are slight slopes and it is accessible by a public road. In its area, there is a school of sculpting in stone. It is partially legally protected (Fig. 13).

4. Limestone quarry from the fifteenth century. Consists of visible market terraces. It is a small site covering about $200 \mathrm{~m}^{2}$. It has an average state of preservation and inconsiderable markings of natural succession (Fig. 14).

5. Quarry where the white kind of "marble" used to be extracted. It covers an area of about $5000 \mathrm{~m}^{2}$. Wellpreserved geological forms make the site extraordinarily picturesque (Fig. 15).

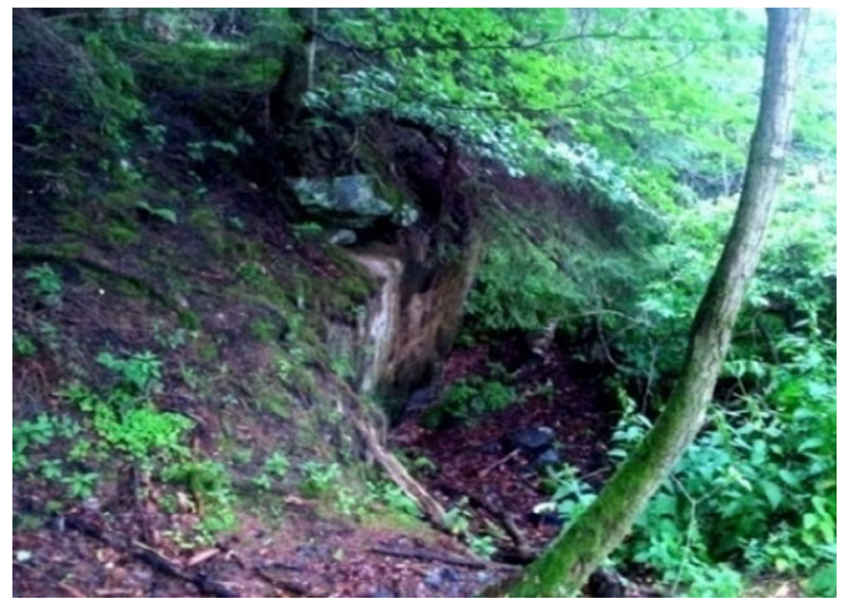

Fig. 8 Quarry no. 8 


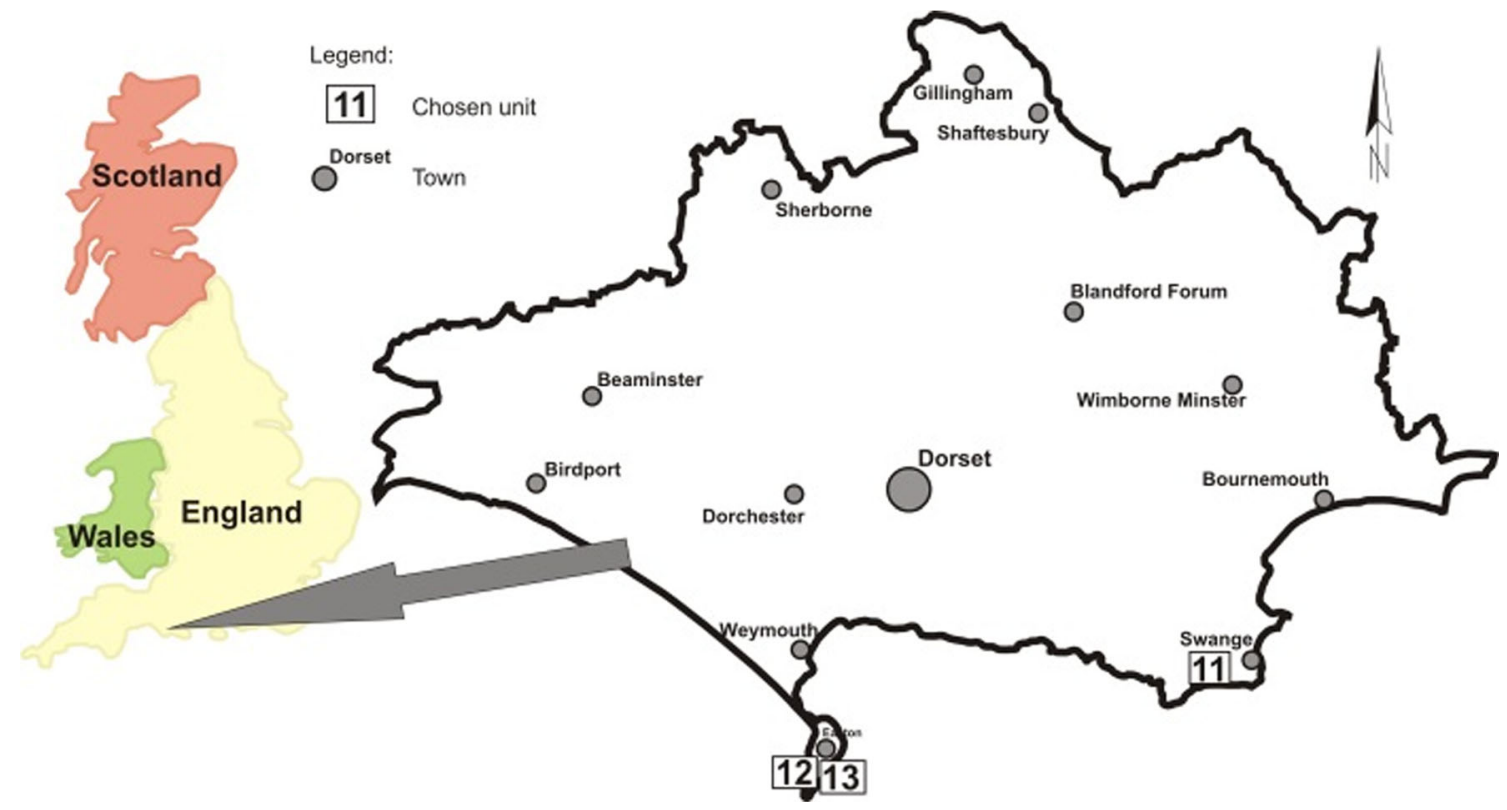

Fig. 9 Location of the British units selected for comparative studies

6. Limestone quarry covering about $1500 \mathrm{~m}^{2}$. A bad state of preservation due to the fast progress of natural succession; additionally, it is naturally filled with water (Fig. 16).

7. Quarry where the red kind of limestone was extracted. It covers an area of about $7500 \mathrm{~m}^{2}$. A very good state of preservation with a perfectly presented geological structure (Fig. 17).

8. Ancient quarry covering about $600 \mathrm{~m}^{2}$, with precisely marked terraces. Naturally filled with water. In its vicinity, there is a museum dedicated to the extraction of rock minerals with an exhibition of extraction techniques and tools (Fig. 18).

9. Limestone quarry covering about $1500 \mathrm{~m}^{2}$. It has steep slopes and an average state of preservation. Natural succession is slowly camouflaging interesting geological profiles (Fig. 19).

10. Quarry where the red kind of limestone was extracted. It has only one picturesque wall. Its other parts have already been covered with vegetation. It covers about $900 \mathrm{~m}^{2}$ (Fig. 20).

\section{Research Result Analysis}

In all of the countries, the research study was conducted during the spring/summer period, both on randomly chosen
Fig. 10 Location of the Austrian units selected for comparative studies

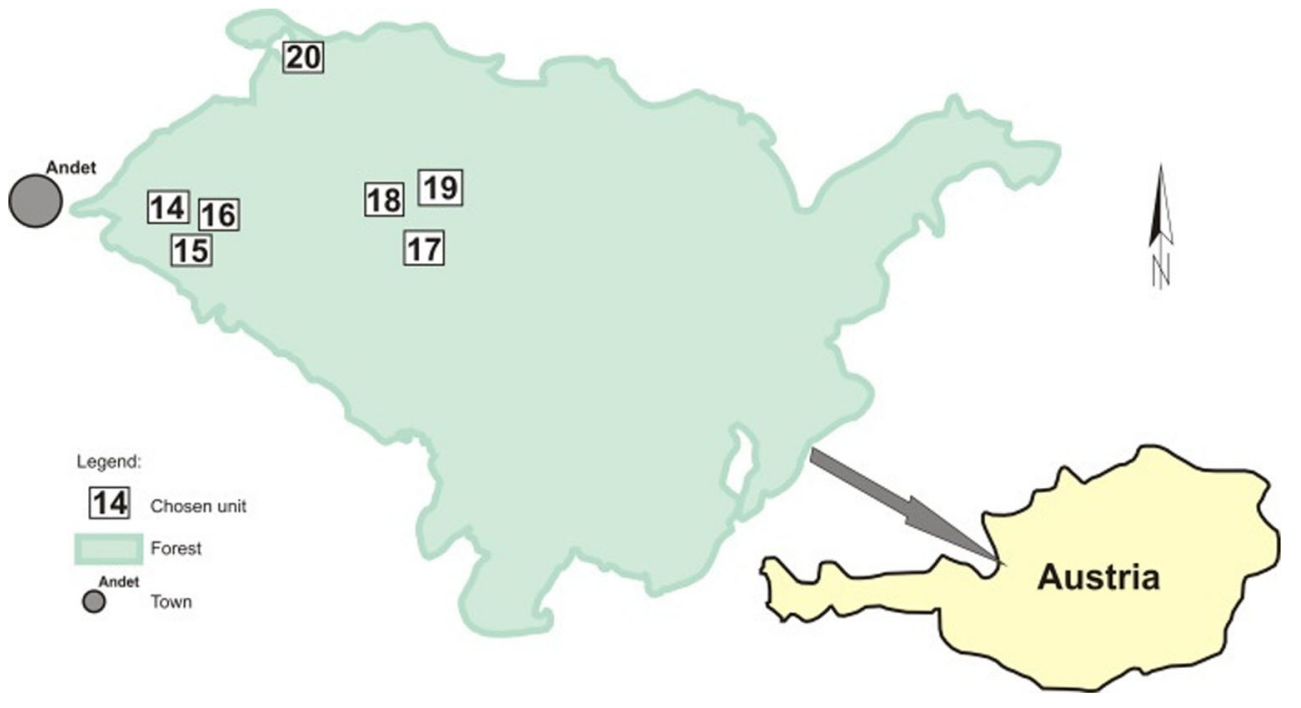




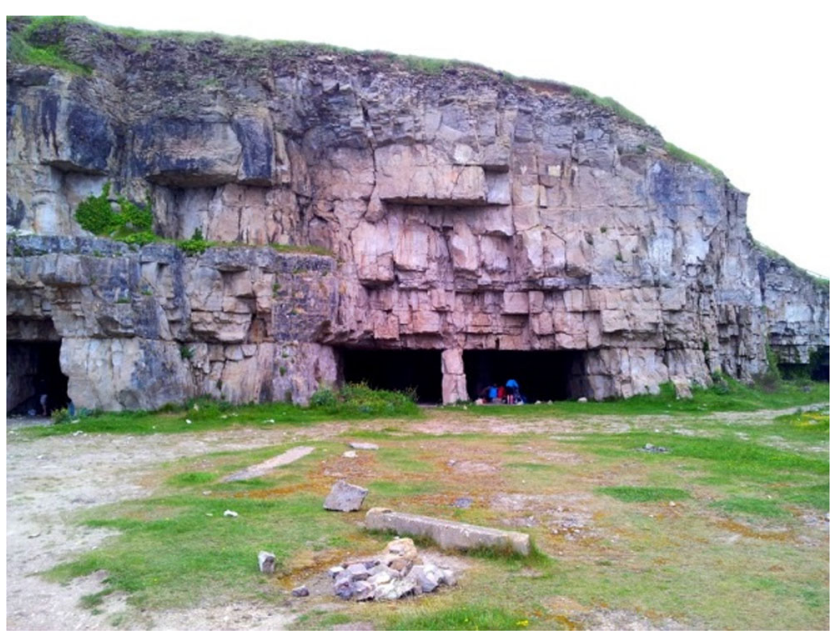

Fig. 11 Quarry no. 11

weekdays and over the weekends. The questionnaire form was filled in during a personal conversation with people visiting the analysed quarries for different reasons and purposes. These were typical tourists, people walking their dogs, horse riders, those interested in swimming, diving, rock climbing, etc. This research study took 2 years and included 1000 respondents in total.

In the survey conducted among respondents in Poland, as many as $82 \%$ of them see the word "quarry" positively, while in England, the percentage is $68 \%$ and in Austria $86 \%$. It is extremely meaningful since positive or negative associations create the will, or lack thereof, for visiting such a place. Only 3\% of Polish and $6 \%$ of English respondents had negative associations. In order to visit an abandoned quarry, $40 \%$ of Poles travel from 11 to $50 \mathrm{~km}$, while in England, the same distance is covered by $26 \%$ of respondents, and in Austria by $30 \%$ of respondents. In England, $76 \%$ of respondents travel smaller distances (from 0 to

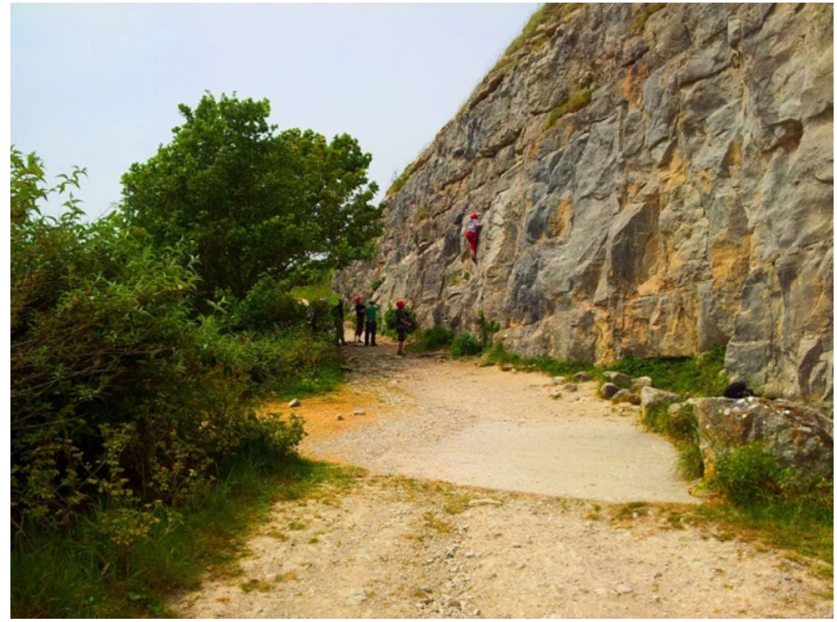

Fig. 12 Quarry no. 12

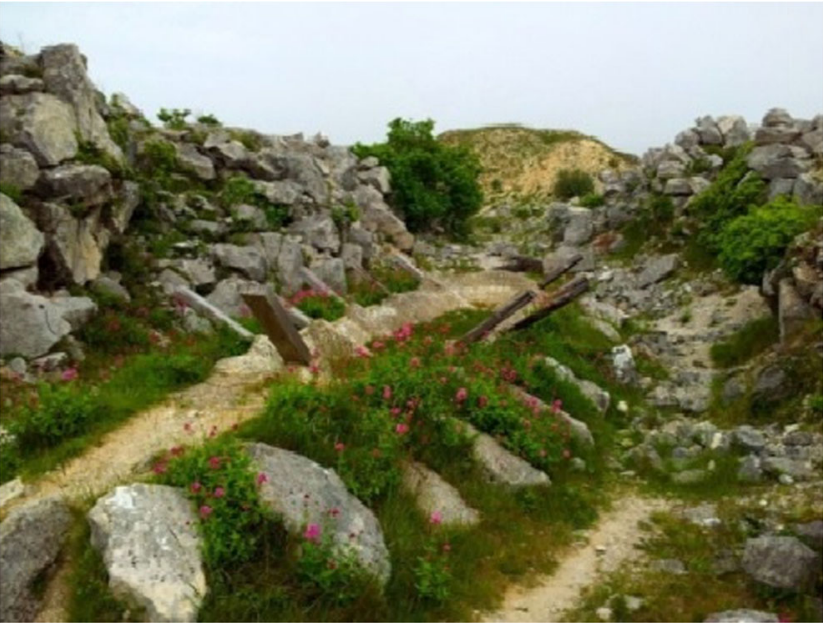

Fig. 13 Quarry no. 13

$10 \mathrm{~km}$ ), while in Austria, such distances are covered by $8 \%$ of respondents. On the other hand, travelling farther than $50 \mathrm{~km}$ is declared by 62,2 , and $26 \%$ of respondents in Austria, England, and Poland, respectively. The results of the study concerning visiting the abandoned quarries show that $21 \%$ of Poles declare using quarries once to twice a year. The same relation in England is $56 \%$, and in Austria $42 \%$, while $34 \%$ of the English and $14 \%$ of the Austrians visit such sites occasionally, just like $57 \%$ of Polish tourists. Forty-four per cent of Austrian respondents, $10 \%$ of English, and $22 \%$ of Polish visit the quarries once a week, twice a week, or more.

The survey was dominated by people aged 18-36: $86 \%$ in Poland, 98\% in England, and 28\% in Austria. The largest group of respondents in Austria comprised people aged $37-65(60 \%)$, while the same age group in England and Poland contributed only 2 and $12 \%$ of visitors, respectively.

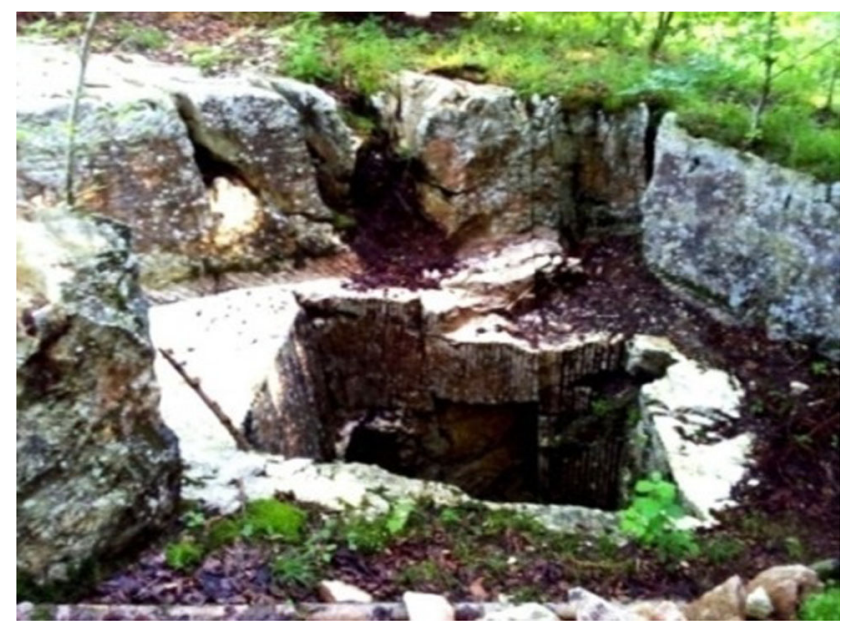

Fig. 14 Quarry no. 14 


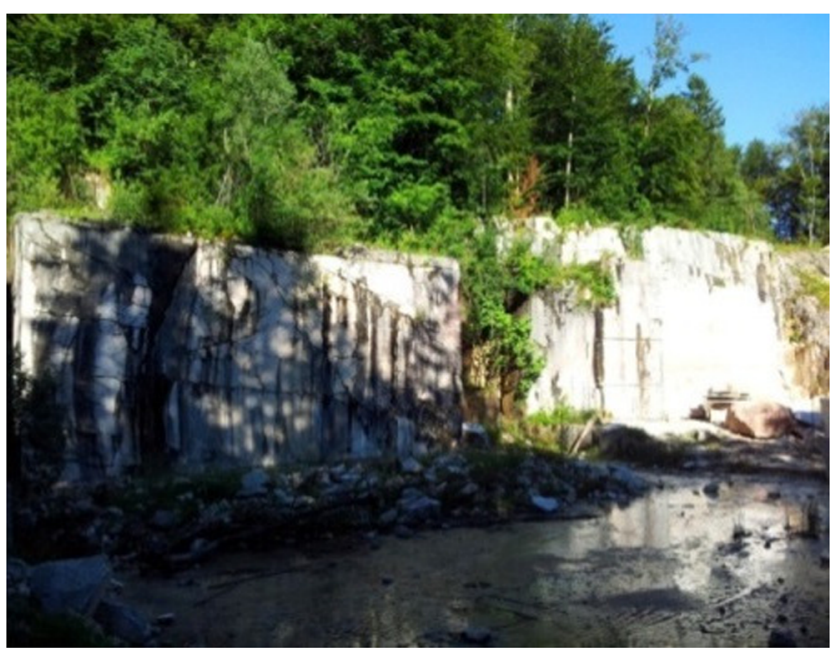

Fig. 15 Quarry no. 15

Based on the answers concerning the assessment of evaluative characteristics provided by the respondents, a polarised graphic profile was drawn for each quarry, and Figs. 21, 22, and 23 show the average assessments for each pair of contrary evaluative characteristics of the studied quarries from the Ślęża Region, Dorset, and the Adnet Region in Austria.

The evaluation of the Ślęża Region quarries is included in the scale from -0.45 to 0.95 . The lowest mark was achieved by the quarries covered with dense vegetation and without high excavation walls. Furthermore, their accessibility for tourists is also hampered. They are evaluated as monotonous, unpleasant, boring, useless, and discordant. Different marks concerning the quarries whose excavation walls are high are scarcely influenced by natural succession and are easily accessible by tourists (quarry nos. 2, 4, 5, 9). They are assessed as differentiated, interesting, intriguing, distinctive, concordant, and natural. They are

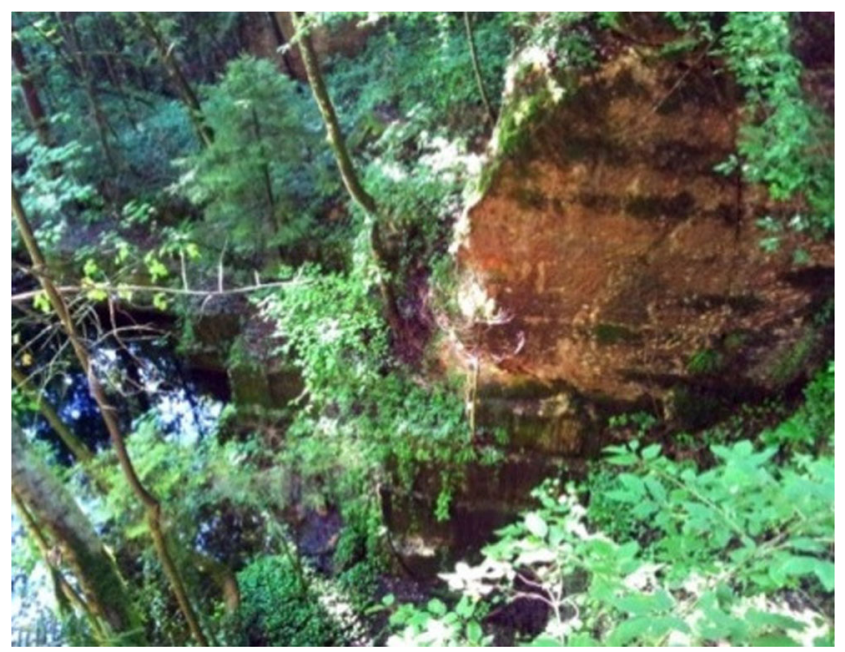

Fig. 16 Quarry no. 16

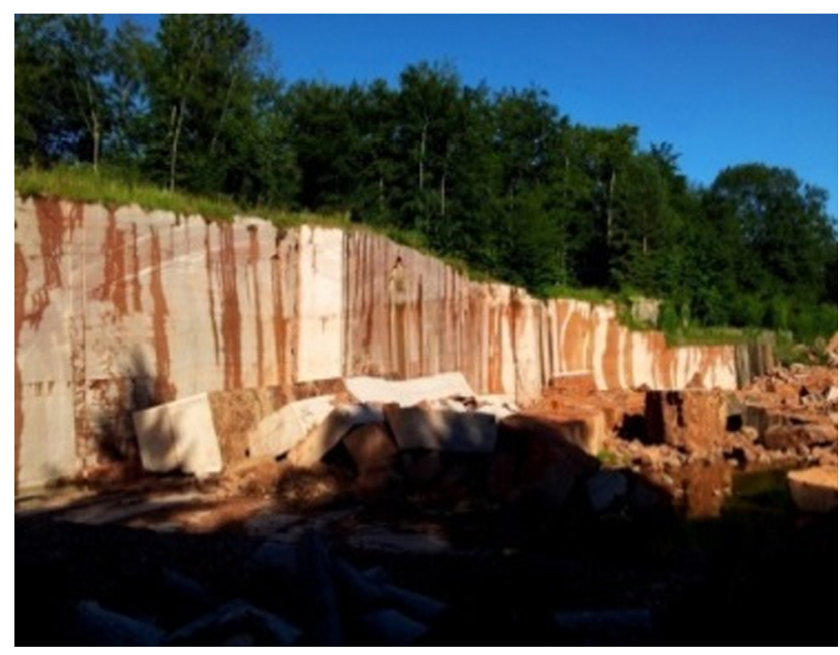

Fig. 17 Quarry no. 17

frequently used by tourists and local inhabitants for rock climbing, and the sites with water for diving and swimming during the summer season.

The quarries in Dorset were marked high by the respondents. First of all, they were evaluated as differentiated, pleasant, intriguing, natural, and concordant. Quarry no. 11 received poor marks and was perceived as dangerous due to its location (near a shoreline of steep cliffs). However, the other two quarries from the area were perceived as safer, since they are not located as close to the shoreline and are not as high. Moreover, according to the respondents, the view of the ocean exalts the contemplation mood; thus, the quarries deserve high marks (pleasant and recreational). Additionally, quarry no. 13 does not have steep slopes, and there is a school of sculpting in stone, which makes it even more interesting and a safe site.

The evaluated quarries in the Adnet Region in Austria, where limestone was extracted, have educational paths and

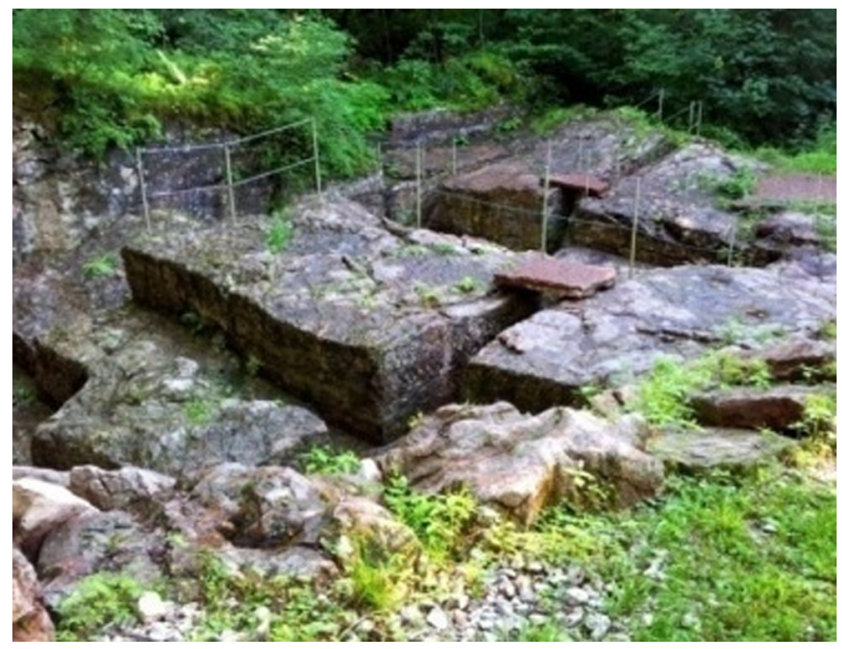

Fig. 18 Quarry no. 18 


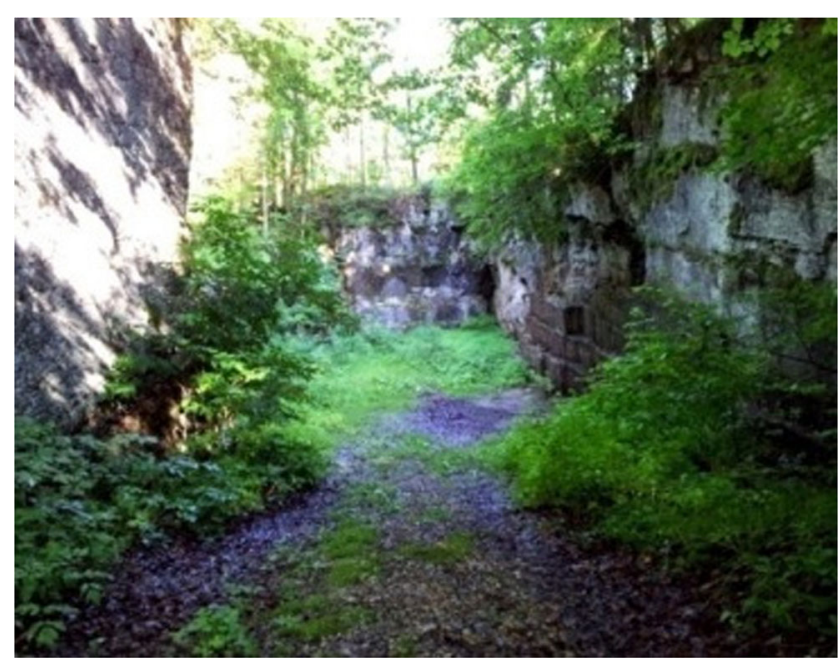

Fig. 19 Quarry no. 19

are protected as historical heritage monuments. The areas were assessed by the respondents positively and received high marks, especially for differentiation and concordance with the neighbourhood. Furthermore, they were assessed as pleasant, relaxing, and natural. Only quarry no. 20 received poorer marks due to its average state of preservation and meaningful influence of natural succession masking interesting forms. The lowest evaluation was that of quarry no. 16. Due to its poor condition and lack of characteristic features, it was perceived as monotonous and unpleasant.

Based on the marks of the respondents, seven point groups were created (Table 2). Then, the 14 studied units were assigned to the partition between 0.60 and 1.29 points, and another six to the following partitions: -0.60 to -0.09 points, and -0.10 to 0.59 points. None of the units were qualified for the lowest point group with solely negative features.

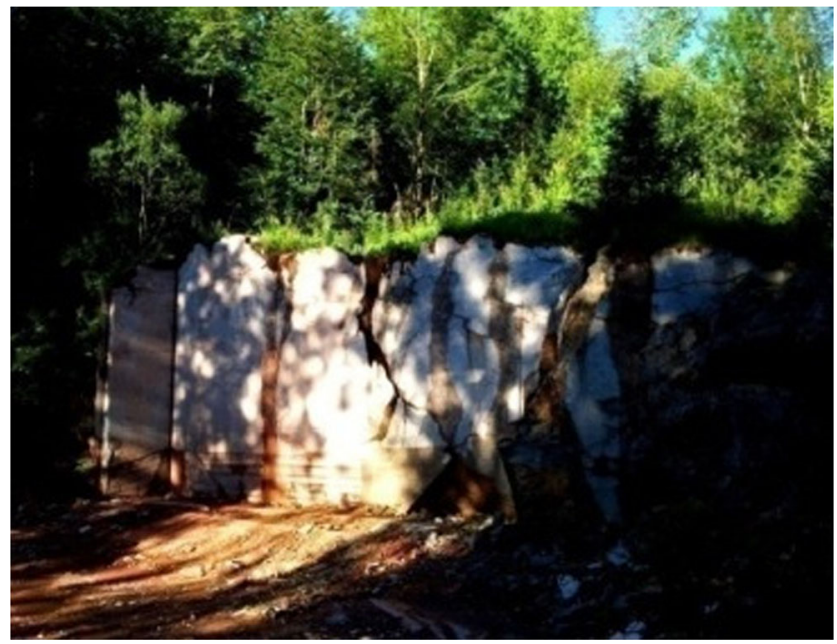

Fig. 20 Quarry no. 20
The survey based on the evaluation of entropy of information sources allows the qualification of quarries into three groups, which was related to the intensity of emitted stimuli. Most quarries (12) were in the second group - stimulating landscapes, whereas another seven were qualified for strongly stimulating landscapes. The results show that quarries are areas emitting many stimuli and, thus, affecting all of the senses. In each of the quarries studied, there were elements reacting to sight, smell, hearing, and touch altogether. The group of strongly stimulating landscapes includes quarries with broad land diversity, broad colour diversity, uncovered profiles, an interesting play of light and shadow, and the changing of scenery and character between day and night. Attention was also paid to the changeability resulting from the changing of the seasons, existence of surface waters, and vegetation. Due to the occurrence of surface waters and vegetation, other stimuli were created, e.g. pleasant sound of water, touch of plants, and occurrence of insects and other animals.

Based on the survey analysis, entropy measurement, and criteria measurement with point bonitation, the quarry landscapes were assigned to four classification groups (Tables 3 and 4).

The very attractive quarry landscapes (group I) have elements such as meaningful vertical differentiation, a good state of quarry preservation, not an advanced level of natural succession, aesthetic appeal, and, thus, a huge contrast to surrounding areas, very good road accessibility, and occurrence of surface waters, which is another element increasing the attractiveness and augmenting chances of quarry utilisation. Furthermore, the survey results also point towards a meaningful interest in these areas and perceiving them to be interesting, differentiated, and natural landscape elements. Their characteristic feature is the biggest entropy indicator, which classifies them as strongly stimulating objects. Moreover, they are located in areas protected in one or a few ways.

The attractive quarry landscapes (group II) usually have a lesser vertical differentiation, and the pace of natural succession is a bit faster; thus, some precious and interesting geological profiles are covered. Furthermore, not all of the quarries in the group have surface waters in their area. Road accessibility is good, and marks of the respondents and entropy are also on a high level. Additionally, they are legally protected.

The slightly attractive quarry landscapes (group III) have elements which decrease their final evaluation. They have little height differences, with access to such a quarry being hindered due to the pace of natural succession. The majority of them do not possess surface waters and do not contrast surrounding areas. Marks of the respondents are much lower, and the entropy 
Fig. 21 Average evaluation for the Ślęża Region

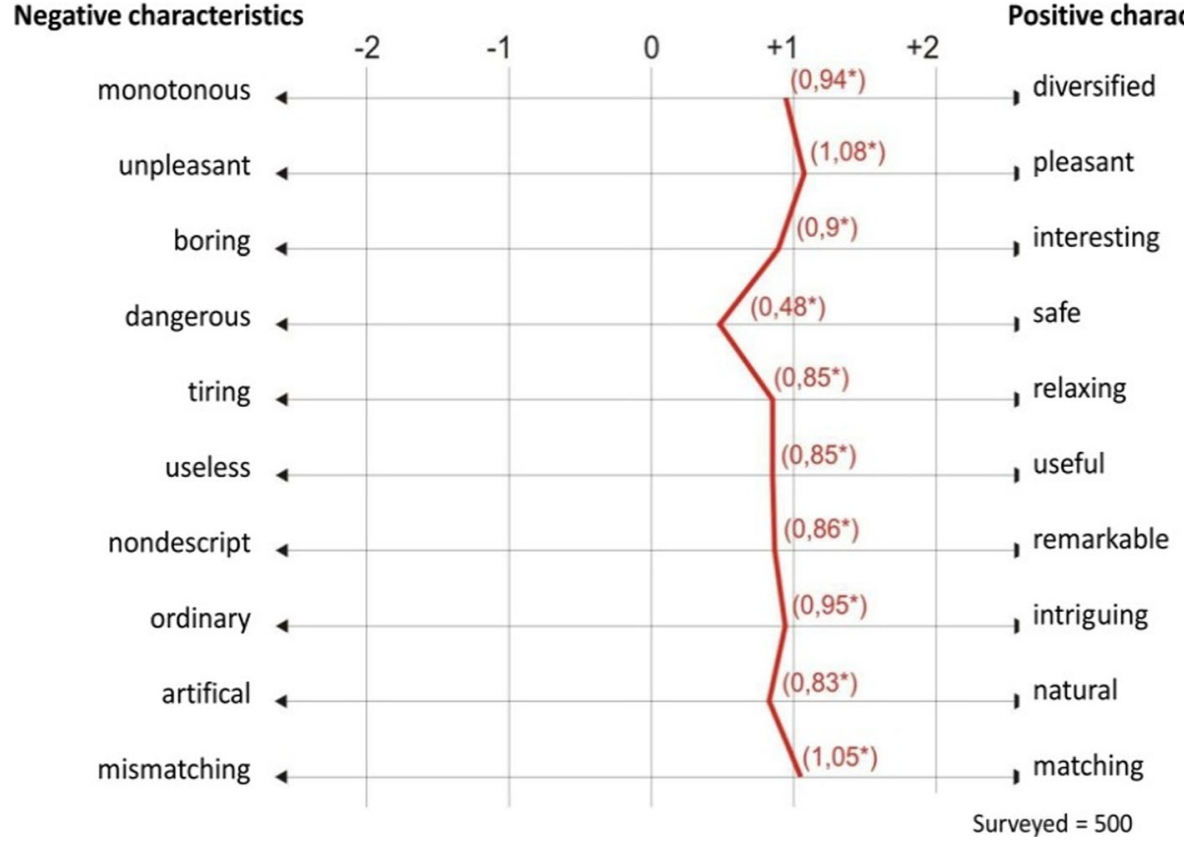

indicator also points towards a much lower probability of various stimuli occurring. However, the areas have a great potential if the right efforts are made, aiming at, for example, decreasing the pace of natural succession or improving road accessibility.

The unattractive quarry landscapes (group IV) have the lowest parameters. They have very little vertical differences, their preservation state is very bad, while the pace of natural succession is meaningful. They do not contrast surrounding areas to such a degree that they remain hardly visible, and a layman cannot distinguish them from the neighbouring area at all. Furthermore, they are not accessible along the set routes. Marks given by the respondents and entropy marks are very low. The quarries from this group are not vividly differentiated and are not perceived as interesting or useful.

The studies in Poland proved that two units are attractive quarry landscapes (nos. 2 and 3), and another two were evaluated as very attractive quarry landscapes
Fig. 22 Average evaluation for Dorset

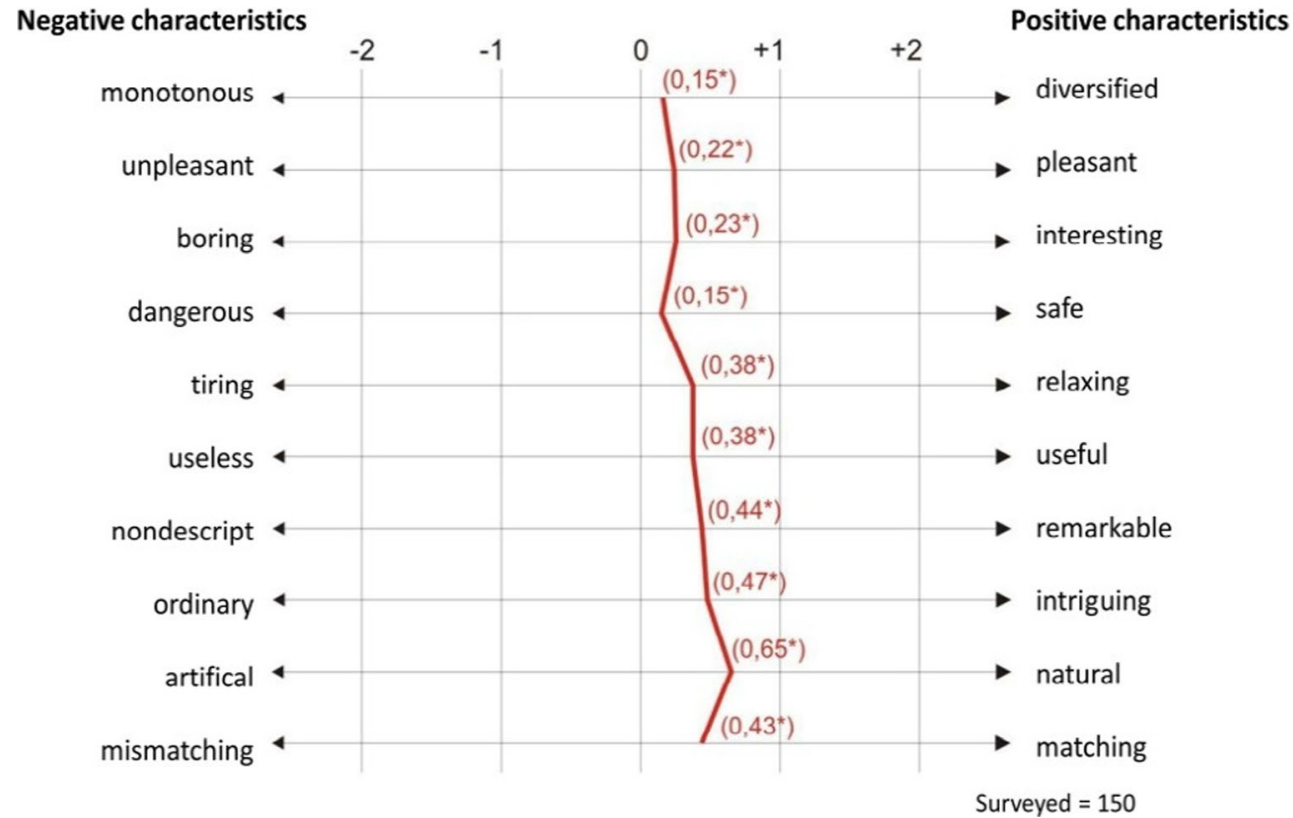


Fig. 23 Average evaluation for the Adnet Region

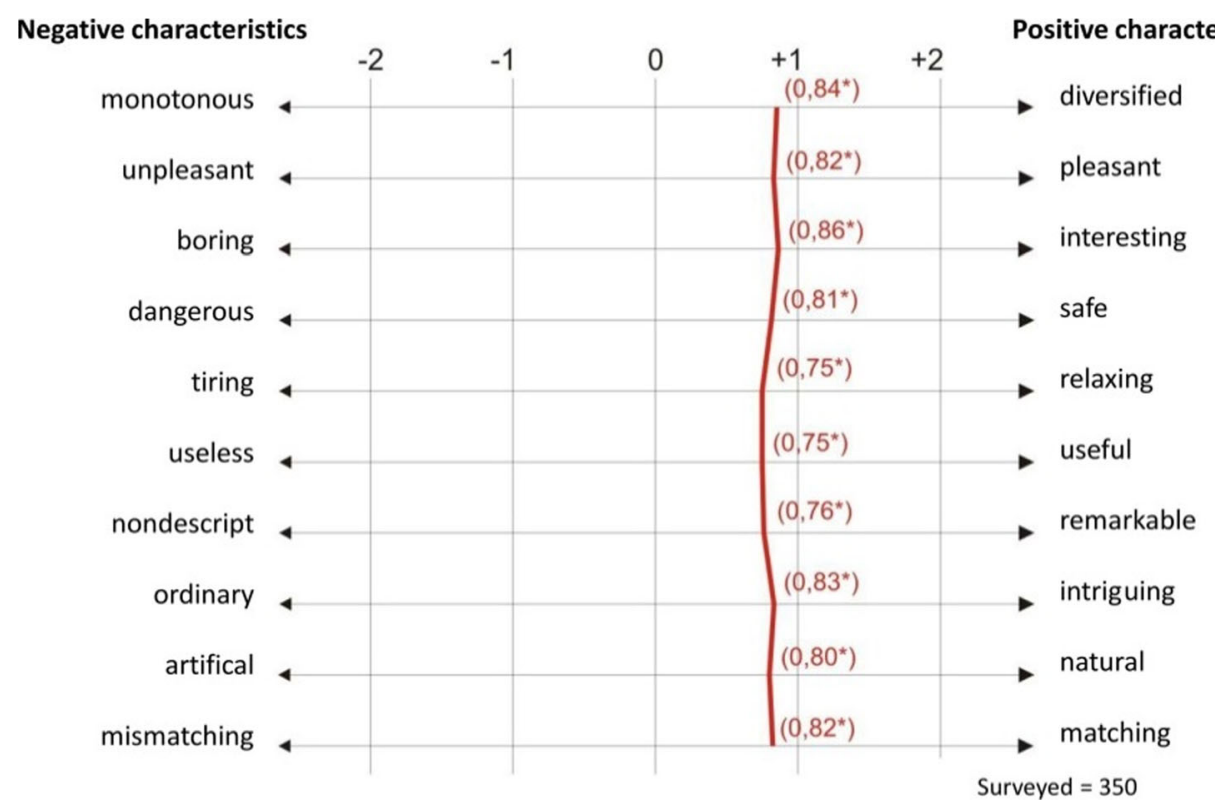

(nos. 4 and 5). Three units were evaluated as slightly attractive quarry landscapes due to the major influence of natural succession that covers evidence of the quarries, and general negligence of the area (nos. 7, 8, and 10). Negatively evaluated, unattractive quarries (three units-nos. 1, 3, and 6) received low marks due to the major natural succession influence, a lack of accessibility, and difficulties with their localisation.

The quarries selected for the study from abroad are very popular among tourists, and they have major landscape attractiveness: as many as seven units were marked as attractive quarries (nos. 12, 13, 14, 15, 17, 18, and 20), and one as very attractive (no. 11). None of the quarries, either in Austria or in Great Britain, were evaluated as having an unattractive landscape. However, two units were qualified as slightly attractive (nos. 10 and 19). Furthermore, all of the studied quarries are subjected to various forms of legal protection and are tourist attractions on already existing tourist routes, facilitating their finding and usages.

Table 3 Number of units resulting from respondents' average evaluation

\begin{tabular}{ll}
\hline Respondents' average evaluation & Number of units \\
\hline From 2.00 to 1.30 & - \\
From 1.29 to 0.60 & 14 \\
From 0.59 to -0.10 & 3 \\
From -0.09 to -0.60 & 3 \\
From -0.61 to -1.30 & - \\
From -1.31 to -2.00 & - \\
\hline
\end{tabular}

The quarries in Great Britain for years have been successfully used as climbing destinations, walking areas, or didactic places. Local powers that noticed their potential use them successfully and encourage people to visit the quarries during events, concerts, art exhibitions, and others that are organised there. In the meantime, tourists may admire the extracted material-in the quarries in Austria, it was limestone of unique colours and structures. Moreover, signboards inform visitors about the history of extraction, geological structure, existing species of fauna and flora, as well as the influence and meaning of the quarries on local life.

\section{Summary}

By considering the issue of the landscape attractiveness of abandoned quarries, we intended to gain information in as broad an area as possible on whether quarry landscape attractiveness exists and how the attractiveness may be increased. In order to do so, the procedure of connection and modification of three methods was proposed: a semantic differential, the method of entropy, and point "bonitation". The verification of the proposed procedure was conducted using selected examples from the Ślęża Region. In order to analyse the issue deeper, comparative studies were carried out in Great Britain and Austria.

During the research, quarry landscape attractiveness level was defined, showing that its main motif is that of quarries' uniqueness, differentiation, as well as interest and curiosity evoked. Quarry areas have elements provoking many stimuli, thus affecting all of the senses (sight, smell, hearing, and 
Table 4 Classification group for the evaluation of abandoned quarries' landscape attractiveness

\begin{tabular}{llll}
\hline Group & Qualification categories & Total points & Number of units \\
\hline I & Very attractive quarry landscape & Over 24 & 3 \\
II & Attractive quarry landscape & From 24.00 to 16.00 & 9 \\
III & Slightly attractive quarry landscape & From 15.99 to 8.00 & 5 \\
IV & Unattractive quarry landscape & Below 8 & 3 \\
\hline
\end{tabular}

touch). Moreover, the study results suggest that such landscape forms are elements enriching a particular area in terms of tourism. Since they are often "side attractions", they can attract larger tourist groups due to their unique nature, special geological phenomena, as well as their historical and cultural values. Furthermore, they determine the future of the area as a tourist resort and may be used for universal social education as a particular feature and make a didactic place that may be incorporated into programmes of recreational and educational trips and science and ecology classes.

Acknowledgments This work was supported by Statute Research Studies (order S40098).

Open Access This article is distributed under the terms of the Creative Commons Attribution 4.0 International License (http:// creativecommons.org/licenses/by/4.0/), which permits unrestricted use, distribution, and reproduction in any medium, provided you give appropriate credit to the original author(s) and the source, provide a link to the Creative Commons license, and indicate if changes were made.

\section{References}

Babbie E (2010) The practice of social researches. Wadsworth, Belmont Bartkowski T (1986) Zastosowanie geografii fizycznej. PWN, Warszawa-Poznań, p 397 (in Polish)

Bartkowski T (1992) Ocena atrakcyjności dla rekreacji krajobrazu multisensorycznego, waloryzacja powierzchni a waloryzacja linii (The assessment of attractiveness of the multisensory landscape for recreation, valorization of the surface and the valorization of the line). In: Chmielewski TJ, Richling A, Wojciechowski HK (eds) Funkcjonowanie i waloryzacja krajobrazu (The operation and valorization of the landscape). Towarzystwo Wolnej Wszechnicy Polskiej Oddział w Lublinie, Lublin (in Polish)

Bernat S (2004) Dźwięk i muzyka w krajobrazie (Relations between sound, music and landscape). In: Perspektywy rozwoju regionu w świetle badan krajobrazowych. Problemy Ekologii Krajobrazu PAEK 4:289-295 (in Polish)

Bezkowska G (2005) Znaczenie estetyki krajobrazu w określaniu walorów turystycznych. Turystyka i Hotelarstwo 8:43-60

Coppin NJ, Box J (1998) Sustainable rehabilitation and revegetation: the identification of after-use options for mines and quarries using a land suitability classification involving nature conservation. In: Fox HR, Moore HM, Elliott S (eds) Land reclamation: achieving sustainable benefits. Proc. of the $4^{\text {th }}$ Int. Conf. Balkema, Nottingham, pp 229-240

Coppin NJ, Bradshaw AD (1982) Quarry reclamation: establishment of vegetation in quarries open pit non-metal mines. Mining Journal Books, London, pp 259-279

Goodall B (1990) In: Ashworth G, Goodall (eds) The dynamic of tourism place marketing. Routledge, New York
Dubel K (2000) Uwarunkowania przyrodnicze w planowaniu przestrzennym. Wyd. Ekonomia i Środowisko, Białystok (in Polish)

Kasztelewicz Z, Ptak M (2011) Rekultywacja terenów górniczych w kopalniach surowców skalnych (Reclamation of post-mining terrains in Polish quarries). Górnictwo i Geologia 39(132):165-176 (in Polish)

Kaźmierczak U, Malewski J (2000) Przyrodnicze zagospodarowanie wyrobisk na przykładzie Kopalni Bazaltu "Uniegoszcz" (Natural developing of mine woids exemplifies of basalt quarry Uniegoszcz). In: Glapa W (ed) Nauka-technika-środowisko, vol 91. Oficyna Wyd. PWr, Wrocław, pp 181-192 (in Polish)

Kaźmierczak U, Strzałkowski P, Baszczyńska M (2014) In: Yianatos J (ed) Natural, geotouristic and recreation attractiveness on postmining "Górażdże" areas. XXVII International mineral processing congress, IMPC 2014. IMPC cop. 2, Chile, pp 10-20

Kothari C R (2004) Research methodology. Methods and techniques, Second edition. Delhi.

Kowalczyk A (2004) Zastosowanie modelu płaty i korytarze do waloryzacji środowiska przyrodniczego dla potrzeb rekreacji (Patch-corrido-matrix model application to natural environment evaluation for recreational needs). In: Cieszewska A (ed.) Problemy Ekologii Krajobrazu, vol. XIV, Warszawa, pp. 1-9 (in Polish)

Kożuchowski K (2005) Walory przyrodnicze w turystyce i rekreacji (Natural values in tourism and recreation). Publishing House, Poznań (in Polish)

Kruczek Z (2011) Atrakcje turystyczne, fenomen, typologia, metody badań (Tourist attractions, phenomenon, typology, test methods). Publishing House Proksenia, Kraków (in Polish)

Leszczycki S (1937) Podhale jako region uzdrowiskowy. Prace Studium Turyzmu Uniwersytetu Jagiellońskiego, Kraków (in Polish)

Leszczycki S (1938) Studia do planu regionalnego w rejonach urbanisyczno-turystycznych. Biuletyn Urbanistyczny 6(3/4) (in Polish)

Lorenc MW, Baczyńska E (2013) Historyczne kamieniołomy na jurajskim wybrzeżu w hrabstwie Dorset (Anglia) (Historic quarries at the jurassic coast county Dorset (England)). Dzieje górnictwa element europejskiego dziedzictwa kultury 5:175-185 (in Polish)

Lorenc MW, Mazurek (2010) Wybrane, nowe propozycje geoturystyczne z Dolnego Ślaska (Selected, new proposals of geotouristic attractions from lower Silesia). Geoturystyka 3(22):3-18 (in Polish)

Malewski J (1999) Zagospodarowanie Wyrobisk. Technologiczne, przyrodnicze i gospodarcze uwarunkowania zagospodarowania wyrobisk poeksploatacyjnych surowców skalnych Dolnego Śląska (Management of excavations. Technological, natural and economic conditions of development of rock materials' post-mining excavation in lower Silesia) Oficyna Wydawnicza P. Wr., Wrocław (in Polish)

Migoń P, Pijet-Migoń E (2015) Overlooked geomorphological component of volcanic geoheritage: diversity and perspectives for tourism industry, Pogórze Kaczawskie Region. Geoheritage, SW Poland. doi:10.1007/s12371-015-0166-8

Młodowski J (1998) Aktywność wizualna człowieka (Visual activity of man). Wydawnictwo Naukowe PWN, Warszawa (in Polish)

Osgood C, Suci G, Tannenbaum P (1957) The measurement of meaning. University of Illinois Press, Urbana and Chicago 
Paulo A (2008) Przyrodnicze ograniczenia wyboru kierunku zagospodarowania terenów pogórniczych (Natural constraints of choosing determined directions of post-mining development). Gospodarka Surowcami Mineralnymi. Mineral Resources Management 24(2/3):9-40 (in Polish)

Polska A (2011) Niematerialne wartości krajobrazów kulturowych (Nonmaterial values of the cultural landscape in historical research as exemplified by boundaries and space). Prace Komisji Krajobrazu Kulturowego, Komisja Krajobrazu Kulturowego PTG 15: 185192 (in Polish)

Raska P, Balej M, Raska M (2011) Differential evolution of rockwall and talus cones in abandoned basalt quarries and its implications for restoration management: case study from the Radobyl Hill, N Chech Republik. International Journal of Mining 25(4):297-312. doi:10.1080/17480930.2011.605547

Rutkowski S (1978) Planowanie przestrzenne obszarów wypoczynkowych w strefie dużych miast. PWN, Warszawa Poznań (in Polish)
Shoval N, Raveh A (2003) Categorization of tourist attractions and the modelling of tourist cities: based on the co-plot method of multivariate analysis. Tour Manag 5:741-750

Steinberg D, Jakobovits L (1971) Semantics. An interdisciplinary reader in philosophy, linguistics and psychology. Cambridge University Press, Cambridge

Swarbroke J (2002) The development and management of visitors attractions, 2nd edn. Butterworth-Heinemann, Oxford

Turski WM (1989) Propedeutyka informatyki (Fundamentals of computer science). Wydawnictwo Naukowe PWN, Warszawa (in Polish)

Śleszyński P (1999) Nowa metoda oceny atrakcyjności wizualnej krajobrazu. Problemy Ekologii Krajobrazu 5:37-55 (in Polish)

Xiao W, Hu Z, Li J, Zhang H, Hu J (2011) A study of land reclamation and ecological restoration in a resource-exhausted city - a case study of Huaibei in China. International Journal of Mining 25(4): 332-341. doi:10.1080/17480930.2011.608888 